\title{
Agricultural Households And Farmer Welfare In North Kolaka Regency
}

\author{
Salahuddin ${ }^{1}$, La Ode Muh Munadi*2, \\ Muhammad Amrullah Pagala², and Rina Astarika ${ }^{3}$ \\ ${ }^{1}$ Agricultural Faculty, Halu Oleo University, Kampus Hijau Bumi Tridharma, Anduonohu, \\ Kendari, Southeast Sulawesi \\ ${ }^{2}$ Faculty of Animal Husbandry, Halu Oleo University, Kampus Hijau Bumi \\ Tridharma, Anduonohu, Kendari, Southeast Sulawesi. \\ ${ }^{3}$ Universitas Terbuka, UPBJJ Yogyakarta, Indonesia \\ ${ }^{*}$ Corresponding author: \\ Email: 1mmunadi@yahoo.com
}

\begin{abstract}
.
The research aims to describe the household loss of food crops, farms, and plantations as well as the welfare of farmers' households in North Kolaka Regency in January-March 2021 referring to national indicators or provisions in the processing of agricultural survey results (ST) that have been conducted by national official institutions, namely the Central Statistics Agency (BPS) of Southeast Sulawesi in 2013 (ST2013) and the results of the Inter-Census middle Survey 2018. The results of the analysis of household income and welfare of agricultural households in North Kolaka Regency showed that food crops in the form of rice 39.36, crops 226.71, farms 12.99, plantations -0.31, and farmers welfare level 6.22.
\end{abstract}

Keywords: Household Violence, Farmer Welfare, North Kolaka

\section{INTRODUCTION}

Agriculture is a culture that was first developed by humans in response to survival challenges that gradually become difficult due to the depletion of food sources in the wild due to the rate of human growth. Agriculture in a broad sense includes people's agriculture or agriculture in the narrow sense called plantations (including people's plantations and large plantations), forestry, livestock, and fisheries (in fisheries known further division of land fisheries and marine fisheries). Development in all areas is the direction and objective of government policy.

The social nature of the development itself is an effort to improve welfare for the entire population. As it is understood, that most of the people of Southeast Sulawesi province live in rural areas and generally still depend on the agricultural sector, so it is expected that the agricultural sector can be the driving force of economic growth that is able to increase the income of farmers and be able to alleviate poverty. North Kolaka District farmers' income improvement program in an effort to alleviate poverty, has been contained in the regional development program strategy. This can be seen from the vision of regional development (2017-2022) namely "North Kolaka as Madani Regency in Southeast Sulawesi". 
In the realization of the vision, there is one mission that is very relevant to efforts to improve the welfare of farmers, namely "to develop and increase intensification, diversification and production of the agricultural and fishery sectors as a whole". This mission includes general efforts in increasing agricultural and fishery production and productivity through intensification and diversification of agricultural and fishery products through processing.Agricultural subsectors include horticulture, food crops, plantations, farms, fisheries and Forestry [1]. Product horticulture includes ornamental plants, medicinal plants, vegetables and fruits has an important role for human beings and the environment [2, 3, 4]. since Reforms from 1997 to 2015, Agriculture is still into a sector that has a revenue per lowest capita compared to the Other. In 2014, productivity per capita agricultural sector is only 0.35 of the productivity national per capita, while for per capita productivity in the mining sector 5.15 or 14.5 times compared to the agricultural sector $[5,6]$.

The success of development in addition to data on economic growth, also required data measuring the level of welfare of the population, especially farmers [7, 8].Agricultural development in Indonesia remains considered the most important of the overall economic development, especially since this agricultural sector be the savior of the economy nationally because of its growth increase, while other sectors negative growth [9]. Indonesia is a Country that has a variety of Agroecositems [10]. Agrosystems or Agricultural Ecosystems is a form of built ecosystem human beings shown to obtain agricultural products that are needed to meet the needs of human [11]. In the context of agricultural home affairs and the welfare of farmers in North Kolaka Regency, it will refer to national indicators or regulations. Where in the processing and analysis of data refers to the results of agricultural surveys (ST) that have been conducted by the official national institutions, namely the Central Statistics Agency (BPS) Southeast Sulawesi in 2013 (ST2013) and the results of the Inter-Census Pertengaan Survey 2018.

\section{METHODS}

The research was conducted in North Kolaka Regency in January-March 2021 using secondary and primary data in collecting empirical facts related to the needs of the Study of the level of welfare and mortality of farmers in North Kolaka Regency. Data analysis used in the preparation of studies on the level of welfare and mortality of farmers is descriptive analysis, to describe the results of conventional field findings in order to provide a systematic, factual and accurate picture of the targets studied. The target in question is the household sufficiency of food crops and farms as well as the welfare of farmers' households in North Kolaka Regency.

\section{RESULT AND DISCUSSION Household Sufficiency subsector of Food Crops}


Food Subsector business includes rice and crops. Based on the results of ST2013 it is known that household food crops in Southeast Sulawesi are dominated by households (RT) that manage crops. Of the total households that manage food crops as much as $134,007 \mathrm{RT}$, there are $62.11 \%(83,213 \mathrm{RT})$ of which manage crops, while households that manage rice plants are as much as $37.82 \%(61,188 \mathrm{RT})$ of all households of food crops. In addition, there are $7.76 \%(10,394 \mathrm{RT})$ of all food crop households in Southeast Sulawesi that manage rice and crops at once.

Types of rice plants in Southeast Sulawesi consists of rice paddy fields and rice fields. The type of rice paddy is more cultivated by households when compared to rice fields. According to ST 2013 data from 61,188 rice crop households in Indonesia, about 83.07 percent $(51,199)$ manage rice paddy crops, while rice fields are only managed by about 16.93 percent $(10,437)$ rice crop households. Furthermore, for households subsectors of food crops in North Kolaka District is presented in Table 1.

Table 1. Household Sufficiency of Food Crop Subsector in North Kolaka Regency 2014-2019

\begin{tabular}{|c|c|c|c|c|}
\hline \multirow[b]{2}{*}{ No } & \multirow[b]{2}{*}{$\begin{array}{l}\text { Subsector } \\
\text { Food Crops }\end{array}$} & \multicolumn{3}{|c|}{ Number of Farmer Households (RT) } \\
\hline & & $\begin{array}{l}\text { Year 2014 } \\
\text { (ST2014) }\end{array}$ & $\begin{array}{c}\text { Year } 2019 \\
\text { (SUTAS2019) }\end{array}$ & $\begin{array}{c}\text { Growth } \\
(\%)\end{array}$ \\
\hline \multirow[t]{3}{*}{1} & North Kolaka: & & & \\
\hline & Rice & 1.725 & 2.404 & 39,36 \\
\hline & Palawija & 850 & 2.777 & 226,71 \\
\hline \multirow[t]{3}{*}{2} & South East Sulawesi: & & & \\
\hline & Rice & 61.188 & 58.456 & $-4,46$ \\
\hline & Palawija & 83.213 & 67.739 & $-18,60$ \\
\hline
\end{tabular}

crops over a period of 5 years (2014-2019) in North Kolaka Regency has increased significantly. In 2014 the number of households for rice commodities amounted to 1,725 and increased in 2019 to 2,404 households, with positive growth of $39.36 \%$. Meanwhile, the number of households for agricultural commodities in 2014 was 850 and also experienced a very significant increase in 2019 to 2,777 households, with positive growth of $226.71 \%$. The phenomenon gives the meaning that people's interest in doing agricultural business, especially in food planting is increasingly enthusiastic. This can be triggered in terms of revenue obtained from increasingly promising agricultural businesses (prospects) [12, 13].

Furthermore, from Table 1 also obtained information that the number of agricultural households in the subsector of food crops during the period of 5 years (2014-2019) in Southeast Sulawesi in general megalami decreased. In 2014 the number of households for rice commodities amounted to 61,188 and decreased in 2019 to 58,456 households, with negative growth of $4.46 \%$. Meanwhile, the number of households for agricultural commodities in 2014 amounted to 83,213 and also experienced a significant decrease in 2019 to 67,739 households, with negative growth 
of $18.60 \%$. The phenomenon gives the meaning that in general the interest of the people in Sulawesi Landmark in doing agricultural business, especially in food planting is decreasing. This can be triggered by the transformation of labor from the farming sector to non-agriculture (mining industry, plantation companies, and or service sector) $[14,15]$.

\section{Home Residential Subsector Of Farms}

The Livestock Subsector business includes large livestock, small cattle, and poultry businesses. An overview of the subsectors of farms in North Kolaka Regency is presented in Table 2 .

Table 2. Households subsector of livestock in North Kolaka Regency in 2014-2019

\begin{tabular}{|c|c|c|c|c|}
\hline \multirow[b]{2}{*}{ No } & \multirow[b]{2}{*}{ Subsector of Farms } & \multicolumn{3}{|c|}{ Number of Farmer Households (RT) } \\
\hline & & $\begin{array}{l}\text { Year 2014 } \\
\text { (ST2014) }\end{array}$ & $\begin{array}{c}\text { Year 2019 } \\
\text { (SUTAS2019) }\end{array}$ & $\begin{array}{c}\text { Growth } \\
(\%)\end{array}$ \\
\hline \multirow[t]{2}{*}{1} & North Kolaka: & & & \\
\hline & $\begin{array}{l}\text { Livestock Food and Non } \\
\text { Food }\end{array}$ & 2.225 & 2.514 & 12,99 \\
\hline \multirow[t]{2}{*}{2} & South East Sulawesi: & & & \\
\hline & $\begin{array}{l}\text { Livestock Food and Non } \\
\text { Food }\end{array}$ & 141.872 & 145.566 & 2,60 \\
\hline
\end{tabular}

Table 2 shows that the number of agricultural households in the subsector of farms over a period of 5 years (2014-2019) in North Kolaka Regency has increased significantly. In 2014 the number of farmhouses was 2,225 and increased in 2019 to 2,514 households, with positive growth of 12.99\%. Meanwhile, from Table 2 also obtained information that the number of households of livestock businesses during the period of 5 years (2014-2019) in Southeast Sulawesi in general also megalami increase. In 2014 the number of farmhouses was 141,872 and increased in 2019 to 145,566 households, with positive growth of $2.60 \%$. The phenomenon gives the meaning that both in Kolaka and Southeast Sulawesi in general, people's interest in doing livestock business, is also increasingly enthusiastic. It can also be triggered in terms of revenue gained from the increasingly prospecting farm business [16].

\section{Housing Keragaan Subsector Plantation}

Subsectors of plantation crops include coconut, coffee, pepper, cocoa, cloves, nutmeg, hazelnut, sago, enau, cashew, and patchouli plants. Household residential subsectors of plantation crops in North Kolaka Regency are presented in Table 3.

Table 3. shows that the number of agricultural households in the subsector of plantation crops over a period of 5 years (2014-2019) in North Kolaka Regency megalami decreased. In 2014 the number of households for subsector commodities of plantation crops amounted to 22,993 and decreased in 2019 to 22,923 households, with negative growth of $0.31 \%$. The phenomenon gives the meaning that the public's interest in doing agricultural business, especially in the subsector of plantation crops. 
International Journal Of Science, Technology \& Management

Table 3. Household Residential Subsector of Plantation Plants in North Kolaka Regency in 2014-2019

\begin{tabular}{llccc}
\hline \multirow{2}{*}{ No } & $\begin{array}{l}\text { Subsector } \\
\text { Plantation plants }\end{array}$ & $\begin{array}{c}\text { Number of Farmer Households (RT) } \\
\text { (ST2014) }\end{array}$ & $\begin{array}{c}\text { Year 2019 } \\
\text { (ST2019) }\end{array}$ & $\begin{array}{c}\text { Growth } \\
\text { (\%) }\end{array}$ \\
\hline 1 & North Kolaka & 22.993 & 22.923 & $-0,31$ \\
\hline 2 & South East Sulawesi & 316.262 & 224.749 & $-40,72$ \\
\hline
\end{tabular}

Furthermore, from Table 3 also obtained information that the number of agricultural households in the subsector of plantation crops during the period of 5 years (2014-2019) in Southeast Sulawesi in general decreased. In 2014 the number of subsector households of plantation crops amounted to 316,262 and decreased in 2019 to 224,794 households, with negative growth of $40.72 \%$.

\section{Agricultural Welfare}

Macro-related, the welfare of agricultural communities is measured through per capita income in the agricultural sector/agricultural productivity, namely the ratio between agricultural GDP and the number of workers involved in the agricultural sector (farmers and laborers) [17]. One important indicator to know the economic condition of a region in a certain period is indicated by GDP data, both on the basis of prevailing prices and on the basis of constant prices [18]. GDP is defined as the amount of added value generated by all business units, or is the amount of final goods and services produced by all economic units in a given region [19]. Gross domestic product (GDP) at the national level and gross regional domestic product (GDP) at the regional (provincial) level, describe the ability of a region to create output (added value) at a certain time [20].

GDP can be interpreted as the value of goods and services produced within the country in a given year [21]. While GDP is the value of goods and services in a country produced by production factors belonging to citizens of those countries and foreign countries [21]. In an economy in developed countries as well as in developing countries, goods and services are produced not only by companies owned by residents of those countries but by residents of other countries [22]. It is always found that national production is created by factors of production that come from abroad. Multinational companies operate in various countries and help increase the value of goods and services produced by these countries [23]. The multinational company provides capital, technology, and experts to the country in which it operates [24].

GDP on the basis of prevailing prices (nominal GDP) is a national income calculated based on the value of goods and services produced by a country in a year and assessed according to the prevailing price of the year [25]. GDP on a valid basis is used to look at shifts and economic structures. This is the way that is always done in calculating national income from one period to another. GDP on the basis of constant price or real GDP is a national income calculated based on the prevailing price of a given year (constant price/price in the base year) which is then used to assess goods 
and services produced in other years [26]. Real GDP is usually used to determine economic growth from year to year.

Its relationship with otput or GDP of the agricultural sector formulates several components that affect the GDP of the agricultural sector including the number of agricultural sector workers and government expenditures (APBD) of the agricultural sector [27]. The results of the estimation of this formulation show that both components have a significant influence on the formation of gdp in the agricultural sector in all districts and cities in Indonesia. Pakasi research results (2005) also build a framework of agricultural GDP model with components such as agricultural sector labor and agricultural sector development expenditure [28]. The results of the total production behavior estimation (GDP) of the agricultural sector showed that the agricultural sector workforce was significant in increasing agricultural GDP, but had an inelastic response to the total agricultural GDP. That is, the increasing number of agricultural sector workers, impacting on the increasing GDP of the agricultural sector, but in the long run the increase changes do not occur quickly. Meanwhile, the results of the analysis of agricultural sector development expenditure components showed an insignificant influence on the increasing number of GDP in the agricultural sector [29].

Technological advances are defined as residual factors to explain economic growth in the long run, and the high low growth itself is assumed to be exogenous or not influenced by other factors [30]. In essence, this model is a development of harroddomar formulation by adding labor and technology factors into the growth equation [31]. Data on per capita income of agricultural sector or agricultural productivity in North Kolaka Regency is presented in Table 4.

Table 4 shows that within 5 years (2014-2019), agricultural sector productivity/growth fluctuated and tended to increase. From the aspect of agricultural labor, it can be seen that the absorption of labor in the agricultural sector from year to year is volatile and tends to increase. In 2014, there were 46,913 working-age people working in the sector, while in 2019 it increased to 51,442 people. This shows that the role of the agricultural sector in providing employment for residents in North Kolaka Regency contributes to an increasing trend and tends to still dominate the job market. Meanwhile, from the aspect of income it is known that the real GDP per capita agricultural sector in North Kolaka Regency every year has increased. In 2014 the real GDP per capita value of the agricultural sector amounted to Rp 40.44 million rupiah per year, while in 2019 it increased to Reach Rp 46.74 million rupiah per year.

Table 4. Development of Farmer Welfare in North Kolaka Regency in 2014-2018

\begin{tabular}{ccccc}
\hline Year & $\begin{array}{c}\text { Agricultural } \\
\text { Labor } \\
\text { (Soul) }\end{array}$ & $\begin{array}{c}\text { PDRB } \\
\text { Agriculture } \\
\text { (Million Rupiah) }\end{array}$ & $\begin{array}{c}\text { GDP Per Capita } \\
\text { Agriculture } \\
\text { (Million Rupiah) }\end{array}$ & $\begin{array}{c}\text { Growth } \\
\text { (\%) }\end{array}$ \\
\hline $\mathbf{2 0 1 4}$ & 46.913 & 1.897 .009 & 40,44 & 13,74 \\
$\mathbf{2 0 1 5}$ & 51.116 & 2.040 .858 & 39,93 & $-1,26$ \\
\hline
\end{tabular}


International Journal Of Science, Technology \& Management

\begin{tabular}{ccccc}
\hline $\mathbf{2 0 1 6}$ & 59.012 & 2.117 .855 & 35,89 & $-10,11$ \\
$\mathbf{2 0 1 7}$ & 59.012 & 2.267 .063 & 38,42 & 7,05 \\
$\mathbf{2 0 1 8}$ & 51.442 & 2.404 .469 & 46,74 & 21,67 \\
\hline Rataan & $\mathbf{5 3 . 4 9 9}$ & $\mathbf{2 . 1 4 5 . 4 5 1}$ & $\mathbf{4 0 , 2 8}$ & $\mathbf{6 , 2 2}$ \\
\hline
\end{tabular}

The figure shows that during the period 2014-2019, agricultural sector productivity in North Kolaka Regency continued to increase with an average growth of $6.22 \% /$ year.

\section{CONCLUSION}

Household income of plantation crops and household welfare of farmers, especially in the subsector of plantations experienced negative growth. As for food crops and livestock increased from 2014-2019.

\section{ACKNOWLEDGMENTS}

The plantation sector in North Kolaka Regency no longer exists well. Thank you to the Government of North Kolaka Regency through the regional RESEARCH and development agency gave us the opportunity to research the level of welfare of farmers in order to formulate a strategy of developing the district's flagship commodity.

\section{REFERENCES}

[1] L. Lathifaturrahmah And A. C. Tridakusumah, "Analysis of Income and Level of Household Welfare of Vegetable Farmers in The Corporate Social Responsibility Program (Case Study In Farmer Group Harapan Jaya Binaan Pt Kaltim Prima Coal)," Agribusiness Pulpit: Journal of Scientific Thinking With Agribusiness Insight, 7(1), Pp. 60-73, 2021.

[2] D. Purbasari, D. L. Setyawan, I. Hardiatama, And M. Trifiananto, "Improving The Welfare of Coffee Farmers Through The Production of Green Coffee With Wet Processing Methods In Sucopangepok Village Jember Regency," Abdi Insani, 8(1), Pp. 72-79, 2021.

[3] B. A. Ferry And Y. Yosefin, "Analysis of The Perception of Farmers In West Mendo Subdistrict, Bangka Province, Bangka Belitung Province, on Warehouse Receipt System Program in Improving Farmers' Welfare" Scientific Journal of Public Management And Social Policy, 5(1), Pp. 71-87, 2021.

[4] B. R. Aprildahani, C. T. H. Permana, And S. T. E. W. Hutama, "Minimum Agricultural Land Needs For Farmers' Welfare On Sumatra Island," Journal Of Science And Applicative Technology, 5(1), Pp. 116-125, 2021.

[5] W. A. Zakaria, T. Endaryanto, L. S. M. Indah, I. R. M. Sari, And A. Mutolib, "Income and Welfare of Cassava Farmers In Lampung Province,"Journal Of Indonesian Agribusiness, 8(1), Pp. 83-93,2020.

[6] K. P. Umar, J. S. Tambas, And M. M. Sendow, "Welfare Level of Coconut Farmer Family in Klabat Village, Dimembe District, North Minahasa Regency," AgriSosioekonomi, 16(2), Pp. 261-268, 2020.

[7] F. Soewignyo And N. Simatupang, "Effect of Changes in Agricultural Commodity Prices on Farmers' Welfare in North Sulawesi Province," Klabat Accounting Review, 1(1), Pp. 
International Journal Of Science, Technology \& Management

14-26, 2020.

[8] A. Priantari, N. Hidayat, And R. Mirasari, "Effect of Pepper Price Change on The Welfare of Pepper Farmers Mega Buana Farmer Group In Batuah Village District Loa Janan Kutai Kartanegara Regency," Jurnal Agriment, 5(2), Pp 91-100, 2020.

[9] S. P. Prayitna, T. I. Noor, And S. Sudrajat, "Analysis of Welfare Level Comparison Between Rice Farmers and Swamp Farmers," Student Scientific Journal Agroinfo Galuh, 7(2), Pp. 310-323, 2020.

[10] S. I. Maulidia And H. Yulistiyono, "The Role of Rural Agribusiness Development Program (Puap) on The Welfare of Farmers in Polagan Village, Galis Subdistrict, Pamekasan Regency," Expansion: Journal of Economics, Finance, Banking, and Accounting, 12(2), Pp. 149-167, 2020.

[11] R. Lalita, R. H. Ismono, And F. E. Prasmatiwi, "Socioeconomic Studies and Household Welfare Levels of Oil Palm Farmers in Tulang Bawang District,"Journal Of Agribusiness Science, 7(2), Pp. 195-202, 2020.

[12] J. Hendrayana, D. Kurniati, And N. Kusrini, "Characteristic Relationship And Level of Welfare of Farmers in Rubber Farming (Case Study In Teraju Village, Toba Subdistrict, Sanggau Regency)," Jurnal Agrica, 13(2), Pp. 144-153, 2020.

[13] E. Basmar And R. Sugeng, "Impact of Financial Activities on Farmers' Welfare in Bulukumba," Seiko : Journal Of Management \& Business, 3(2), Pp. 37-45, 2020.

[14] J. Arifin, "Poverty Culture in Poverty Alleviation in Indonesia," Sosio Informa, 6(2), Pp. 114-132, 2020.

[15] S. Supriyadi, "Mobilization Cadres: Efforts to Empower Family Welfare in Pakis Subdistrict, Magelang, "Welfare : Journal of Social Welfare Sciences, 8(2), Pp. 119139, 2019.

[16] R. A. P. Setiawan, T. I. Noor, L. Sulistyowati, And I. Setiawan, "Analisis Tingkat Kesejahteraan Petani Kedelai Dengan Menggunakan Pendekatan Nilai Tukar Petani (Ntp) Dan Nilai Tukar Pendapatan Rumah Tangga Petani (NTPRP)," Jurnal Agribisnis Terpadu, 12(2), Pp. 178-189, 2019.

[17] H. H. Setiawan, "Formulating Social Welfare Index (Iks) in Indonesia," Sosio Informa, 5 ( 3), Pp. 208-222, 2019.

[18] M. Sabarisman, "The Role of Sub-District Social Welfare Workers in Improving The Welfare of Families of Food Social Assistance Beneficiaries," Sosio Informa, 5(2), Pp. 145-161, 2019.

[19] R. Ridayanti And B. Nuswantara, "Relationship Between Farmer Characteristics, Farmer Perception And Socioeconomic Support Level With The Decision of Farmers To Grow Rice Varieties Ciherang In Rogomulyo Village District. Kaliwungu, Regency. Semarang," Agrika, 13(1), Pp. 1-9, 2019.

[20] S. S. Pamusu, H. Harianto, K. Kuntjoro, And R. Winandi, "Impact of Production Risk on Household Welfare of Shallot Farmers in Sigi Regency," Journal Economics of Agriculture And Agribusiness, 3 (2), Pp. 429-438, 2019.

[21] E. Nurhadi, S. I. Hidayat, P. N. Indah, S. Widayanti, And G. I. Harya, "Keberlanjutan Komoditas Kakao Sebagai Produk Unggulan Agroindustri Dalam Meningkatkan Kesejahteraan Petani," Agriekonomika, 8(1), Pp. 51-61, 2019.

[22] N. Novindra, S. M. Bonar, D. R. B. Sinaga, Hastuti, F. F. I. Adif, And A. Dea, "Impact of Poverty Alleviation Assistance on Farmers' Production, Income and Household Welfare," Journal Of Agriculture, Resource And Environmental Economics, 2(1), Pp. 88-99, 2019.

[23] W. N. Khasanah, K. Murniati, And S. Widjaya, "Income and Welfare of Households Of Rice Farmers In Sidomulyo Subdistrict, South Lampung Regency," Journal Of Agribusiness Science, 6(4), Pp. 430-436, 2019. 
[24] H. Hamzah, A. Idhan, And S. Syamsia, "Dissemination of Agricultural Waste Management Technology Into High Economic Value Products In An Effort to Support Farmers' Welfare," Journal of Community Dedication, 2(2), Pp. 83-91, 2019.

[25] T. I. Datau, S. Canon, And A. Halid, "Level of Welfare of Farmer Households According to Community Typology," Jambura Agribusiness Journal, 1(1), Pp. 26-35, 2019.

[26] A. A. Rasyid And B. Budyanra, "Determinant of Welfare of Food Farmers in Aceh Province 2012-2017,"Darussalam Journal Of Economic Perspectives, 4(2), Pp. 178198, 2018.

[27] M. Martina And R. Praza, "Analysis of Rice Paddy Farmers' Welfare In North Aceh Regency," Agrifo : Journal of Agribusiness Malikussaleh University, 3(2), Pp. 27-34, 2018.

[28] L. R. Lampah, P. Oktavianus ., And G. H. M. Kapantow, "Family Welfare Level of Rice And Corn Farmers In Matani Village, Tumpaan District, South Minahasa Regency," Agri-Sosioekonomi, 13(3), Pp. 397-406, 2018.

[29] C. M. Keumala And Z. Zainuddin, "Indikator Kesejahteraan Petani Melalui Nilai Tukar Petani (NTP) Dan Pembiayaan Syariah Sebagai Solusi," Economica: Jurnal Ekonomi Islam, 9(1), Pp. 129-149, 2018.

[30] A. Ainurrahma, N. R. Nuryartono, And S. H. Pasaribu, "Farmer Welfare Analysis: Land Tenure Pattern in Lamongan Regency," Journal of Economic and Development Policy, 7 (2), Pp. 102-117, 2018.

[31] N. Amalia And A. Nurpita, "Analysis of Farmers' Welfare Dynamics in East Java Province," Journal of Accounting, Economics and Business Management, 5(2), Pp. 222-227, 2017. 